\title{
ZNACZENIE EUROPY ŚRODKOWO-WSCHODNIEJ W ZIMNOWOJENNYCH KONCEPCJACH POLSKIEGO WYCHODŹSTWA NA TLE POTENCJALU WIELKICH MOCARSTW
}

\section{UWAGI WSTĘPNE}

Historia Europy Środkowo-Wschodniej jest obrazem nieustannych, toczonych od wieków, kampanii przeciwko wyniszczającym najazdom ze wschodu i zachodu, które upoważniają do ciągłego podejmowania dyskusji o - jak czasami pisano „największym politycznym przeciągu świata”. Kolejny po zakończeniu II wojny światowej kryzys polityczny w stosunkach międzynarodowych z przełomu lat 40. i 50. ubiegłego wieku, będący następstwem wczesnej fazy zimnowojennej konfrontacji budził wśród środkowoeuropejskich kół emigracyjnych ogromne nadzieje na zmianę niekorzystnych dla nich rozstrzygnięć w następstwie potencjalnego starcia państw zachodnich i Bloku Radzieckiego. Zadaniem wychodźstwa, nie tylko polskiego, miało być przyjęcie na siebie aktywnej roli we włączaniu uwolnionej od komunizmu Europy Środkowo-Wschodniej do obozu sojuszniczego Zachodu, ale także ponoszenie początkowego wysiłku zbrojnego w zakresie niezbędnym do osiągnięcia tegoż celu. Podstawą realizacji była wola jej ówcześnie ujarzmionych narodów do decydowania o własnej podmiotowości oraz brak ich akceptacji dla porozumienia opartego jedynie na przemocy, nawet jeżeli było ono akceptowalne przez część świata politycznego, jak to miało miejsce w latach II wojny światowej. Przedstawiciele tych średnich i małych państw, uważając je za niemoralne i nierealne do utrzymania w dłuższej perspektywie, postulowali przywrócenie ładu w stosunkach międzynarodowych opartego na równości wszystkich wobec pra-

Dr hab. Leszek Pawlikowicz, prof. UR - Kolegium Nauk Społecznych, Instytut Nauk o Polityce Uniwersytetu Rzeszowskiego; e-mail: lpawlik@ur.edu.pl. ORCID ID: 0000-0002-4389-1937.

Dr ROBERT ZAPART - Kolegium Nauk Społecznych, Instytut Nauk o Polityce Uniwersytetu Rzeszowskiego; e-mail: robert.zapart@onet.poczta.pl. ORCID ID: 0000-0002-3590-1189.

1 Z.S., Federacja Zachodnio-Słowiańska, „Biuletyn Zachodnio-Słowiański” [Edinburgh] 1940, nr 1, s. 3 . 
wa z możliwością skutecznego zastosowania powszechnych sankcji w przypadku jego złamania. W tym kontekście ewentualne przyszłe rozwiązania, aby były całkowicie dobrowolne, miałyby wypływać z uznanych norm moralności międzynarodowej gwarantującej harmonijne współdziałania wielu społeczności. W ocenie wychodźstwa nie należało przesądzać, czy z perspektywy bezpieczeństwa Europy Środkowo-Wschodniej miała to być regionalna, czy też szersza forma federacji lub konfederacji. Podkreślano natomiast

konieczność ukształtowania takiej wspólnoty, która z jednej strony możliwie w najmniejszym stopniu ograniczy suwerenne prawa państw czy ich grupy, a z drugiej, należycie zabezpieczy centralnym organom wykonawczym i ustawodawczym dostatecznie szeroki zakres uprawnień umożliwiających jej stabilizację wewnętrzną i godną pozycję zewnętrzną określoną sformułowaniem ,power” w stosunkach międzynarodowych. Oznaczałoby to także początek nowej ery dla tej części kontynentu, a także stwarzałoby podstawy przyszłej równowagi i stabilizacji sił w świecie, kładąc być może kres niemiecko-rosyjskiej rywalizacji, kończąc lub ograniczając polską doktrynę bezpieczeństwa opartą o dwóch przeciwników, a także ograniczając pola do politycznej intrygi na Międzymorzu innym zainteresowanym jego destabilizacją ${ }^{2}$.

Wiązało się to z przekonaniem jego narodów o konieczności przyśpieszenia w przyszłości procesu regionalnej integracji i zaproponowania nowych warunków współżycia w ramach jednego podmiotu liczącego ponad 100 milionów osób, z wieloma wyznaniami religijnymi, kilkunastoma językami i tyluż odmiennymi kulturami i nawarstwionymi od wieków różnego rodzaju sporami. Kluczowe jednak pozostawało pytanie o kształt Europy Środkowo-Wschodniej oraz jej ewentualnie niezależną, z perspektywy posiadanego potencjału gospodarczo-militarnego, pozycję w systemie kontynentalnego i światowego bezpieczeństwa w następstwie obserwowanego rozwoju stosunków międzynarodowych. Próbę odpowiedzi na to pytanie podejmą autorzy poniższej refleksji naukowej, zwiastującej szersze podjęcie w przyszłości powyższej tematyki.

\section{DOKTRYNALNY KONFLIKT MOCARSTW O SYSTEM ZBIOROWEGO BEZPIECZEŃSTWA}

Obserwowana od drugiej połowy lat 40. XX wieku zmiana w stosunkach międzynarodowych, a szczególnie pogarszające się relacje pomiędzy ZSRR i Stanami

${ }^{2}$ R. ZAPART, Projekt Konstytucji Federacji Środkowo-Europejskiej jako wyraz integracyjnego idealizmu w budowie systemu regionalnego bezpieczeństwa w myśli politycznej polskiego wychodźstwa w XX wieku, ,Studia Polonijne”39(2018), s. 271. 
Zjednoczonymi, sprzyjały przyjętym przez środowiska przymusowego wychodźstwa założeniom. Kryzys berliński z $1948 \mathrm{r}$. był pierwszym poważnym testem amerykańskiej polityki powstrzymywania komunizmu. Upadek (i ewakuacja na Tajwan) popieranego przez Waszyngton rządu Czang-Kaj-Szeka w Chinach, wybuch wojny koreańskiej oraz złamanie przez Sowietów monopolu atomowego przekonały polityków Zachodu do rozbudowy potencjału militarnego, wdrożenia planów integracji stref okupacyjnych $w$ jeden podmiot (Republika Federalna Niemiec) oraz zawarcia porozumienia polityczno-wojskowego - Sojuszu Północnoatlantyckiego ${ }^{3}$. Przywoływany okres, to również czas sporów wokół systemu globalnego i kontynentalnego bezpieczeństwa, będący pokłosiem różnic ideologicznych pomiędzy Wschodem a Zachodem oraz w amerykańskich i europejskich stanowiskach dotyczących roli Organizacji Narodów Zjednoczonych, stosunku do ekspansji światowego komunizmu, miejsca odbudowywanych Niemiec, a także alternatywnego wobec NATO i lansowanego przez Francję projektu Europejskiej Wspólnoty Obronnej ${ }^{4}$. Zmieniająca amerykańskie nastawienie do komunizmu doktryna prezydenta Trumana związana z „obroną wolności narodów wszędzie gdziekolwiek jest ona zagrożona", upoważniała największe mocarstwo do ponownego wzięcia odpowiedzialności za Europę oraz pozostawione na sowiecką łaskę w jej środkowo-wschodniej części narody. Była ona także ważnym aktem w toczonej przez Stany Zjednoczone przeciwko ideologicznemu przeciwnikowi na Starym Kontynencie wojnie psychologicznej, której częścią stał się Plan Marshalla, wzmacniający odbudowę jego gospodarczo-militarnego potencjału.

Sowiecką doktrynę wojenną zdefiniowali Lenin i Stalin, przy czym słowa tego ostatniego, że ,zadaniem politycznej strategii jest przede wszystkim wyznaczenie głównego kierunku ruchu proletariackiego w danym kraju, w danym okresie historycznym", w najlepszym stopniu oddają cele ideologii komunistycznej ${ }^{5}$. Jej ofensywnym narzędziem stała się wymierzona w przeciwników wroga propaganda, uzupełniona finalnie działaniami wojennymi. W krajach satelickich Europy Środkowo-Wschodniej przybrało to formę opartej o aparat represji sowietyzacji

3 K. MichaŁeK, Mocarstwo, czyli historia Stanów Zjednoczonych Ameryki 1945-1992, Warszawa 1995, s. 51-58; A. Mania, The National Security Council i amerykańska polityka wobec Europy Wschodniej w latach 1945-1960, „Zeszyty Naukowe Uniwersytetu Jagiellońskiego” 1994, t. 52, s. 30-105.

${ }^{4}$ R. ZAPART, Polityczno-militarne znaczenie oddziałowych kół wojskowych z perspektywy potencjalnego światowego konfliktu w latach 50. XX wieku, w: Bezpieczeństwo Europy, bezpieczeństwo Polski, t. V: Metamorfozy bezpieczeństwa, teraźniejszość i przyszłość, red. E. Maj, W. Sokół, A. Szwed -Walczak, Ł. Jędrzejewski, Lublin 2017, s. 389-391.

${ }^{5}$ S. R., Kilka uwag o doktrynie wojennej Stanów Zjednoczonych i Rosji sowieckiej, „Bellona” [Londyn] 1948, z. 1, s. 8. 
wszelkiej publicznej aktywności, natomiast w pozostałych państwach, będących przedmiotem zainteresowania Moskwy, a w szczególności w krajach zachodnich „preparację umysłów” ich społeczeństw przez niszczącą wewnętrznie i wspieranej przez nią działalność środowisk lewicowych.

Tym samym Sowieci alternatywnymi środkami kompensowali niższy od amerykańskiego poziom efektywności techniki wojskowej, starając się doprowadzić do równowagi potencjałów wojskowych. W ówczesnej geopolityce, zarówno Polska, jak i inne mniejsze państwa Europy Środkowo-Wschodniej odgrywały po II wojnie światowej rolę biernych obiektów w rękach zwycięskich mocarstw, szczególnie że dwa największe - Stany Zjednoczone i Rosja, w drugiej połowie lat 40. XX wieku wkroczyły w epokę militarnego wykorzystywania energii atomowej. Ta ostatnia stała się podstawą ich przewagi nad innymi podmiotami państwowymi i strategicznym narzędziem realizowania odmiennych z uwagi na ideologie celów polityczno-gospodarczych. Oparcie się o tak zaawansowane technicznie wynalazki skutkowało zawężeniem się przestrzeni zmagań, a wartość obronna, w tym warunki naturalne i poziom społecznego zaangażowania, traciły na swoim klasycznym znaczeniu. Przyjęta zatem przez dwa wielkie mocarstwa strategia światowego działania odzwierciedlała tkwiące w nich siły polityczne, militarne i ekonomiczne. Na pierwszy plan doktrynalnego konfliktu o panowanie nad powojennym światem wysuwały się głębokie różnice w koncepcjach ustrojowych, które rzutowały na fiasko utworzenia zbiorowego systemu bezpieczeństwa. Powstały w jego następstwie pod parasolem nuklearnym, oparty o demokratycznie funkcjonujące państwa Zachodu - Sojusz Północnoatlantycki, mierzył się z komunistyczną Rosją i podporządkowanymi jej państwami Europy Środkowo-Wschodniej. Charakter tego konfliktu powodował, że kluczowego znaczenia nabrały zagadnienia wyposażenia sił zbrojnych w nowoczesny i stale odnawiany sprzęt, którego strumień dostaw musiał być skorelowany $\mathrm{z}$ odpowiednim zapleczem gospodarczym. Miernikiem możliwości prowadzenia ówcześnie wojny, a przede wszystkim osiągania zakreślonych celów politycznych, stało się posiadanie zdolności do wystawienia i utrzymania odpowiedniej dla odstraszania potencjalnych przeciwników armii. Zaspokojenie jej wszystkich potrzeb wymagało wytworzenia adekwatnego potencjału gospodarczo-militarnego, w którego skład wchodziło wiele różnych czynników, w tym: wielkość dochodu narodowego, poziom produkcji przemysłowej, wartość usług, wysokość wydatków, wielkość zasobów ludzkich itp. Bardzo istotna była również możliwość szybkiego zwiększenia wysiłku wojennego całego społeczeństwa, nawet kosztem znaczącej obniżki standardów jego życia. Struktura sił zbrojnych Zachodu była logicznym odbiciem amerykańskiej doktryny wojennej, w której przodującym rodzajem sił zbrojnych stały się siły powietrzne (będące wówczas zarazem kluczowym nośnikiem środków masowego 
rażenia) predestynowane do odegrania rozstrzygającej roli w wojnie ze Wschodem. Pozostałe wojska odgrywały w dużej części rolę pomocniczą i wtórną, wykazując przy tym odpowiednią potęgę uderzenia oraz wysoką ruchliwość strategiczną i taktyczną. Ponieważ całość tych sił miała się składać również z kontyngentów pozostałych państw Sojuszu Północnoatlantyckiego, traktowanych jako jeden rezerwuar, wprowadzono zasadę, według której każde z nich miało dostarczyć do wspólnej obrony te komponenty lądowe, morskie i powietrzne, które może wystawić w wyniku swego położenia geograficznego, możliwości gospodarczych oraz zasobów ludzkich. W ten sposób Zachód miał wystawić armię, której potencjału nie mógłby uzyskać przy systemie nakładania wysiłków partnerów jednego na drugi. W ramach przyjętych rozwiązań, Stany Zjednoczone miały dostarczyć strategiczne lotnictwo bombowe, a także z Wielką Brytanią większość sił morskich, natomiast Europa jako całość, większość początkowych sił lądowych, które byłyby uzupełnione $\mathrm{w}$ zależności od rozwoju wydarzeń przez amerykańskiego sojusznika ${ }^{6}$. Potencjał Stanów Zjednoczonych, a szczególnie wzrost liczebności jego armii (po okresie demobilizacji 1946-1947) u progu ,zimnej wojny” w latach 1948-1949 obrazuje tabela 1.

Tabela 1. Wzrost liczebności armii Stanów Zjednoczonych

\begin{tabular}{|c|c|c|c|c|c|}
\hline Data & $\begin{array}{c}\text { Total Natio- } \\
\text { nal Military } \\
\text { Establish- } \\
\text { ment }\end{array}$ & Army & Navy & $\begin{array}{c}\text { Marine } \\
\text { Corps }\end{array}$ & Air Force \\
\hline $\begin{array}{c}\text { Total: } \\
\text { 1948: }\end{array}$ & & & & & \\
June 30 & $1,445,910$ & 554,030 & 419,162 & 84,988 & 387,730 \\
Dec. 31 & $1,625,838$ & 678,990 & 447,029 & 87,507 & 412,312 \\
1949: & & & & & \\
Jan. 31 & $1,668,492$ & 714,059 & 450,358 & 88,499 & 415,576 \\
June 30 & $1,615,360$ & 660,473 & 449,575 & 85,965 & 419,347 \\
Officers: & & & & & \\
1948: & 169,458 & 68,178 & 45,416 & 6,907 & 48,957 \\
June 30 & 185,950 & 76,984 & 47,683 & 7,335 & 53,948 \\
Dec. 31 & & & & & \\
1949: & 189,321 & 78,472 & 48,090 & 7.325 & 55,434 \\
Jan. 31 & 190,348 & 77,272 & 47,975 & 7,250 & 57,851
\end{tabular}

${ }^{6}$ B.M., Doktryny wojenne i struktury organizacyjne sił zbrojnych Zachodu i Wschodu, „Bellona” [Londyn] 1951, z. 3, s. 47-48. 
Enlisted and officer

candidates:

1948:

$\begin{array}{llllll}\text { June } 30 & 1,276,452 & 485,852 & 373,746 & 78,081 & 338,778 \\ \text { Dec. 31 } & 1,439,888 & 602,006 & 399,346 & 80,172 & 358,364\end{array}$

1949:

\begin{tabular}{lrrrrr} 
Jan. 31 & $1,479,171$ & 635,587 & 402,268 & 81,174 & 360,142 \\
June 30 & $1,425,012$ & 583,201 & 401,600 & 78,715 & 361,496 \\
\hline
\end{tabular}

Źródło: Second Report of the Secretary of Defense and the annual reports of the Secretary of the Army, Secretary of the Navy, Secretary of the Air Force for the Fiscal Year 1949, United States Government Printing Office, Washington 1950, p. 318.

Państwa zachodnie dysponowały ówcześnie nowoczesną doktryną wojny powietrzno-lądowo-morskiej, natomiast Związek Sowiecki i państwa satelickie doktryną przede wszystkim wojny lądowej. Te pierwsze mogły wystawić sprawne narzędzia zdolne do uzyskania celów w krajach przeciwnika, te drugie masę żołnierską stojącą u wrót na Stary Kontynent. W ostatecznym rozrachunku, z uwagi na posiadanie przez Stany Zjednoczone oraz Związek Radziecki broni masowego rażenia o zwycięstwie którejkolwiek ze stron nie przesądzałoby czasowe zajęcie określonego terenu, lecz złamanie woli walki połączone z implozją systemu politycznego. Już sam „zimnowojenny” wyścig zbrojeń, a niekoniecznie kolejny militarny konflikt dawał pewne szanse na upadek niewydolnego społecznie i gospodarczo komunizmu, a w następstwie odzyskanie tą drogą niepodległości przez państwa Europy Środkowo-Wschodniej.

\section{EMIGRACJA POLSKA O KONCEPCJACH FEDERACYJNYCH I POTENCJALE SPOŁECZNO-GOSPODARCZYM EUROPY ŚRODKOWO-WSCHODNIEJ}

Przywykliśmy uważać, że największym gwarantem politycznej niezawisłości państwa są jego siły zbrojne, stanowiące o wartości w stosunkach międzynarodowych. Olbrzymi rozwój techniki w połowie XX wieku, zweryfikowany w sferze militarnej przez ostatnią wojnę, zmusił dotknięte jej skutkami średnie i mniejsze podmioty Europy Środkowo-Wschodniej do weryfikacji powyższego poglądu. Samotne ponoszenie ciężaru konfliktu w starciu ze zdecydowanie silniejszym przeciwnikiem byłoby zbyt dużym ryzykiem, jak miało to miejsce w przeszłości w przypadku Czechosłowacji, Polski lub państw bałtyckich. Żadnemu z krajów nie udało się obronić niezawisłości, aczkolwiek historia każdego z nich wymagałaby z pewnością nieco innego spojrzenia na przyczyny z uwagi na poziom ich świadomego oporu, który również z kontekście tych naukowych rozważań może być potężną 
uzupełniającą bronią. Ogromne nadzieje wiązały one z hipotetycznym kolejnym globalnym starciem pomiędzy ZSRR oraz Stanami Zjednoczonymi. Zwycięski dla bloku alianckiego wynik miał pozwolić na odbudowę ich niepodległości. Szczególną uwagę wśród emigracyjnych reprezentantów ujarzmionych narodów Europy Środkowo-Wschodniej poświęcono ideom federalistycznym i związanym z nim mechanizmom budowania wspólnoty, i to pomimo kategorycznego sprzeciwu Stalina oraz fiaska wcześniejszych planów zbudowania polsko-czechosłowackiej federacji, która miała być jednym z politycznych osiągnięć rządu gen. Władysława Sikorskiego i częścią większego planu środkowoeuropejskiego ${ }^{8}$. Największym powodzeniem cieszyła się koncepcja utworzenia, wzorowanej na Radzie Europy, Rady Narodów Europy Środkowo-Wschodniej, mającej być zaczynem przyszłej regionalnej wspólnoty odgrywającej w przyszłości rolę równorzędnego partnera dla dominujących ówcześnie w stosunkach międzynarodowych państw9 ${ }^{9}$ Nie pomijano w tych rozważaniach, niezbędnego dla powodzenia projektu, zaangażowania Zachodu gwarantującego docelowo jego bezpieczeństwo. Nie przeszkadzał

${ }^{7}$ A. ZAĆMIŃSKI, Emigracja polska w Wielkiej Brytanii wobec możliwości wybuchu III wojny światowej 1945-1954, Bydgoszcz 2003, s.150-151.

${ }^{8}$ R. ZAPART, Projekt Konstytucji, s. 251-279; K. MochlińsKi, Polskie inicjatywy Federacji Europy, w: Akcja niepodległościowa na terenie międzynarodowym 1945-1990, red. T. PIESAKOwsKi, Londyn 1999, s. 143-165; T. KomARnICKI, Próba stworzenia związu polsko-czeskiego w okresie II wojny światowej, „Sprawy Międzynarodowe” 1(1947), nr 2-3, s. 62-82; K. TARKA, Konfrontacja czy wspótpraca? Litwa w polityce Rządu Polskiego na uchodźstwie 1939-1945, Opole 1998, s. 31-32; H. BARToszewicz, Polityka Zwiazku Sowieckiego wobec państw Europy Środkowo-Wschodniej w latach 1944-1948, Warszawa 1999, s. 7; E. ZNAMIERowsKa-RaKK, Federacja Stowian Poludniowych w polityce Butgarii po II wojnie światowej, Warszawa 2005, s. 71-72. Szerzej: P. Wandycz, L. FrendL, Zjednoczona Europa. Teoria i praktyka, Londyn 1965; M. KukIEL, Ksiązę Adam, Warszawa 1993; R. WaPIŃski, Historia polskiej myśli politycznej XIX i XX wieku, Gdańsk 1997; K. GrYGaJTis, Polskie idee federacyjne i ich realizacja w XIX i XX wieku, Częstochowa 2001; F. Gross, Federacje i konfederacje europejskie. Rodowód $i$ wizje, Warszawa 1994; T. KIsIELEwsKI, Federacja środkowoeuropejska. Pertraktacje polsko-czechostowackie 1939-1943, Warszawa 1991; S. WolaŃsKi, Europa Środkowo-Wschodnia w myśli politycznej emigracji polskiej 1945-1975, Wrocław 1996; A. FRISZKE, Życie polityczne emigracji, Warszawa 1999; R. HABIELSKI, Życie społeczne i kulturowe emigracji, Warszawa 1999; Warszawa nad Tamiza. Z dziejów polskiej emigracji politycznej po drugiej wojnie światowej, red. A. Friszke, Warszawa 1994; V. Jezerník, Západoslovanská Federální Unie, LondonEdinburgh 1942. Ciekawie na tym tle prezentowały się opinie jednego ze współpracowników byłego premiera Niemiec, Stressemana (zdymisjonowanego po dojściu Hitlera do władzy), który popierał rozwój Federacji Słowian Zachodnich, odrzucając jednak korektę granic na korzyć Polski oraz liczbę podmiotów ją tworzących (Polska, Czechosłowacja, ,Nowe Prusy”), aby nie stanowiła zagrożenia dla północnego i zachodniego sąsiada (Niemcy), a była faktycznie ich zapleczem społeczno-gospodarczym, E. Stern-Rubarth, Exit Prussia: a plan for Europe, London 1940, s. 17, 22-23, 90, 208-209.

9 P. MachCewicz, Emigracja w polityce międzynarodowej, Warszawa 1999, s. 53-54. 
w tym politykom emigracyjnym początkowy jego désintéressement, przejawiający się w uznaniu części naszego kontynentu za strefę wyłącznych wpływów Moskwy. Nauczone doświadczeniem klęski zwróciły one bowiem większą uwagę na konieczność poszukania wewnętrznego kompromisu pozwalającego podmiotowo je wzmocnić w przyszłych negocjacjach z Zachodem. Punktem wyjścia do rozmów przedstawicieli ponad 150 milionów Europejczyków zamieszkujących Międzymorze Adriatycko-Bałtycko-Czarnomorskie, był brak akceptacji dla nowego porządku świata opartego na strefach wpływu, które uznawano za niemoralne i nierealne do utrzymania $\mathrm{w}$ dłuższej perspektywie ${ }^{10}$. Położenie geograficzne, przeszłość historyczna, wspólnota cywilizacyjna i struktura społeczna uzasadniały w ich mniemaniu możliwość połączenia się w jeden organizm (nieokreślony co do ostatecznej formy i liczby podmiotów), który prowadziłby wspólną politykę zagraniczną, obronną, a także współdziałałby zmierzając do unii celnej w sferze gospodarczej oraz kulturalnej ${ }^{11}$. Nie były to łatwe i konstruktywne rozmowy, z uwagi na to, że niektórzy politycy byli przekonani o wiodącej roli własnego kraju w tej części kontynentu, stąd praktycznie rozważano realnie powrót do federacji polsko-czechosłowackiej poszerzonej o Węgry (dzisiejsza Grupa Wyszehradzka) oraz większej wspólnoty liczącej około $120 \mathrm{mln}$ osób, w której dodatkowo widziano państwa bałtyckie - Albanię, Austrię, Bułgarię, Jugosławię i Rumunię ${ }^{12}$.

Spekulacyjnym koncepcjom politycznym środowisk wychodźczych towarzyszyły projekty wojskowe, które po wejściu Zachodu w otwarty konflikt zbrojny z blokiem komunistycznym w Korei, w połowie 1950 r. zyskały na dynamice przygotowań. Szczególną aktywnością wykazywały się środowiska polskie, które na bazie potencjału osobowego likwidowanego Polskiego Korpusu Przysposobienia i Rozmieszczenia, wchodzących w dorosłość nowych rocznikach poborowych zgrupowanych w oddziałowych kołach wojskowych oraz w harcerstwie, widziały możliwość odtworzenia narodowych sił zbrojnych. Bazowano na doświadczeniach poprzedniej wojny, gdy walczono u boku zachodnich aliantów ${ }^{13}$. W środowiskach

10 S. WolańSKI, Europa Środkowo-Wschodnia $w$ myśli politycznej emigracji polskiej 19451975, Wrocław 1996, s. 84-85; R. ZAPART, Projekt Konstytucji, s. 273-274.

${ }^{11}$ K. Locher, Konfederace nebo federální unie?, „Biuletyn Zachodnio-Słowiański” [Edinburgh] 1942, nr 1, s. 7-11; Z. STACHOWSKI, The federation of Central European nations, tamże, nr 9, s. 3-4, 6; G. Zlatoper, Federation in the common interest, tamże, s. 7-8; J. MaLIK, Economic aspects of post-war recontruction, tamże, s. 11-13; Z.S., Zwiazek polityczny narodów Europy Środkowej, „Biuletyn Zachodnio-Słowiański” 1941, nr 3, s. 3-15; Z.S., Federacja Zachodnio-Słowiańska, „Biuletyn Zachodnio-Słowiański” 1940, nr 2, s. 3-11.

${ }_{12}$ K. Grygajtis, Polskie idee, s. 476.

13 S. KopaŃski, Wspomnienia wojenne 1939-1946, Warszawa 1990, s. 410-411; R. ZAPART, Polityczno-militarne znaczenie, s. 389-408. 
wychodźczych powszechnie podzielano przekonanie, że tylko stanowiąca wyodrębnioną strukturę operacyjną pod dowództwem alianckim armia polska powinna walczyć o niepodległość kraju, zapewniając mu później odpowiedni poziom bezpieczeństwa ${ }^{14}$. Z uwagi jednak na sytuację polityczną dopuszczano podjęcie współpracy wojskowej z sojusznikami bez warunków wstępnych, w tym formalnoprawnych gwarancji nawiązania stosunków dyplomatycznych z władzami RP na uchodźstwie ${ }^{15}$. Mniej elastyczności wykazywano w przypadku pojawiających się zwrotnie koncepcji wykorzystania Polaków oraz innych przymusowych emigrantów w „legiach cudzoziemskich”, które miałyby pozostawać w składach armii państw zachodnich. Bez entuzjazmu do tych działań podchodziła część państw zachodnich pod egidą Francji, zmierzających ówcześnie do utworzenia Europejskiej Wspólnoty Obronnej zakładającej zintegrowanie nowych sił zbrojnych z powstałym w 1949 r. Sojuszem Północnoatlantyckim. Ten projekt jednak nie przewidywał tworzenia jednostek narodowych złożonych ze środkowoeuropejskich emigrantów, a także utrzymywania relacji z ich politycznymi przedstawicielami, stąd zawarte przez Republikę Federalną Niemiec i Francję porozumienia o odbudowie w ramach EWO armii niemieckiej, bez jednoczesnego zagwarantowania Polsce trwałości granic zachodnich, określano mianem „drugiego Locarno” ${ }^{16}$. Argumentowano przy tym, że forsowanie remilitaryzacji Niemiec może przynieść korektę prozachodnich nastrojów w krajach regionu, a w następstwie zmienić układ sił z uwagi na ich potencjał militarny, który mógłby być przedmiotem innego od założeń zachodnich wykorzystania. Negatywne skutki powyższych działań miałaby ograniczyć pełna kontrola NATO nad armią niemiecką, uzyskanie gwarancji, że nie zostanie ona użyta do rewizji granic na Odrze i Nysie, a także utworzenie w ramach Sojuszu Północnoatlantyckiego ,niepodległych sił zbrojnych polskich oraz innych krajów Europy Środkowo-Wschodniej"17. Oceniano, że liczba zdolnych do służby wojskowej, a przebywających na emigracji około 170 tys. Polaków, pozwoli na przełomie roku 1948/49 utworzyć z nich 3-4 dywizje piechoty, 1 dywizję pancerną i jedną spadochronową, 6-9 dywizjonów lotniczych, a nawet zapewnić załogi dla lekkiego krążownika i 2-3 łodzi podwodnych. Oceniano dodatkowo, że w przyszłości można wykorzystać w kraju 800 tys. oficerów i żołnierzy uznanych za ideowo antykomunistycznych ${ }^{18}$. Później możliwości polskiego wychodźstwa nieco skorygowano

14 A. ZAĆMiŃSKI, Emigracja polska, s. 220-267.

15 P. MachCewicz, Emigracja, s. 77.

16 J. ZdZIEChOwski, Polish Affairs 1952, nr 6, s. 18.

${ }^{17}$ Fragment Memoriału Egzekutywy Zjednoczenia Narodowego na konferencję 9 państw w Londynie z września 1954 r. w: P. MACHCEwicz, Emigracja, s. 69-70.

${ }^{18}$ Archiwum Instytutu i Muzeum gen. Sikorskiego w Londynie [dalej: AIPMS], sygn. A.XIX 1/8, Plan tworzenie PSZ na Zachodzie ze stycznia 1953 r., s. 3-4; Z. WoŹNicZKA, Trzecia wojna świa- 
w kontekście przygotowania wojskowego związanego z wystawieniem pełnoetatowych jednostek, zwiększając stany do 11 tys. oficerów oraz 160 tys. szeregowych przeszkolonych i nieprzeszkolonych ${ }^{19}$. Zdecydowanie niżej, bo na około 32 tys. łącznie, szacowano możliwości pozostałego środkowoeuropejskiego wychodźstwa $^{20}$. Dla porównania liczebność sił zbrojnych ZSRR i państw satelickich szacowano na około $6,25 \mathrm{mln}$ przeszkolonych oficerów i żołnierzy, z tego od 1,15 $\mathrm{mln}$ do $1,35 \mathrm{mln}$ z tych drugich (bez wschodnich Niemiec i Albanii) oraz około $0.45 \mathrm{mln}$ formacji wewnętrznych (milicja, inne) ${ }^{21}$.

Tabela 2. Liczebność sił zbrojnych

\begin{tabular}{|c|c|c|c|c|c|}
\hline \multirow[b]{2}{*}{ Country } & \multirow[b]{2}{*}{ Population } & \multicolumn{2}{|l|}{ Strength } & \multicolumn{2}{|c|}{ Number of Divisions } \\
\hline & & Armed forces & $\begin{array}{l}\text { Internal } \\
\text { Defence }\end{array}$ & April 1952 & April 1953 \\
\hline Polska & 25 & $430.000-450.000$ & 100.000 & 20 & 24 \\
\hline Czechosłowacja & 12.4 & $170.000-190.000$ & 60.000 & 12 & 15 \\
\hline Węgry & 9.2 & $135.000-260.000$ & 50.000 & 9 & 12 \\
\hline Bułgaria & 7.1 & $170.000-200.000$ & 40.000 & 11 & 11 \\
\hline Rumunia & 6.2 & 250.000 & 200.000 & 12 & 14 \\
\hline Total & 59.9 & $1.155 .000-1.350 .000$ & 450.000 & 64 & 76 \\
\hline
\end{tabular}

Opracowanie własne na podstawie: AIMPS, sygn. A. XIX. 1/50, Memorandum to the Supreme Command of the Armed Forces of the Atlantic Pact in Europe, 1952, s. 2; Polish Affairs 1952, nr 6, s. 18.

Społeczeństwo polskie, podobnie jak pozostałe społeczeństwa w krajach satelickich, miało być w tych przygotowaniach bierne, skupiając swoją uwagę na zabezpieczeniu biologicznych podstaw funkcjonowania w reżimie komunistycznym $^{22}$. Nie wchodząc $\mathrm{w}$ tym miejscu głębiej zarówno w zagadnienia polityczne, jak i militarne związane z ewentualną integracją państw regionu, przyglądnijmy się ich wspólnemu i indywidualnemu potencjałowi społeczno-gospodarczemu, bazując na obowiązujących przed II wojną światową rozwiązaniach terytorialnych ${ }^{23}$. Pierwszym rozważanym parametrem będzie ludność, a w szczególności jej charakterystyka demograficzna i struktura zawodowa. Według statystyki Ligi Narodów z lat 1938-1939, omawiany region zamieszkiwało 118, 6 mln osób, przy czym największa

towa $w$ oczekiwaniach emigracji i podziemia $w$ kraju w latach 1944-1953, Katowice 1999, s. 230; P. MACHCEWICZ, Emigracja, s. 81.

${ }_{19}$ AIMPS, sygn. A.XIX 1/49, Propozycje polskie na konferencję w dniach 26 i 30 lipca 1952 r., s. 2.

\footnotetext{
20 Tamże, sygn. A.XIX. 1/50, k. 4-7.

${ }^{21}$ Z. WoŹNICZKA, Trzecia wojna światowa, s. 235.

22 A. ZAĆMIŃSKI, Emigracja polska, s. 38-196; P. MACHCEWICZ, Emigracja, s. 68.

${ }^{23}$ Szersze ujęcie tematu będzie przedmiotem odrębnej pracy monograficznej.
} 
gęstość zaludnienia występowała w krajach bardziej uprzemysłowionych (Czechosłowacja, Austria, Polska, Węgry), a niska w pozostałych, i wynosiła odpowiednio od 308 osób (Śląsk) do 40 osób (Albania) na km². Analogiczny obraz dawała statystyka przyrostu naturalnego, przy czym kraje wyżej uprzemysłowione wykazywały się niższymi wskaźnikami, a niżej (w tym Polska) - wyższymi. Pomimo ocenianych na 10-12 mln strat wojennych, wskazywano w emigracyjnych symulacjach, że w latach 50. XX wieku ludności Międzymorza będzie liczyć pomiędzy 120 a 130 milionów osób, a struktura wieku będzie zbliżona do krajów zachodnich ${ }^{24}$. Zdecydowanie gorzej prezentowały się perspektywy szybkiego skorygowania niekorzystnej dla niego struktury zawodowej. Dominował, z wyjątkiem Czechosłowacji i Austrii, rolnik, przy czym dodatkowo odbiegał on swoimi kwalifikacjami od wykonujących powyższą profesję w krajach zachodnich, co było następstwem wcześniejszych procesów historycznych zachodzących w tej części kontynentu w Monarchii Austro-Węgierskiej, Cesarstwie Rosyjskim i Imperium Ottomańskim ${ }^{25}$. Dwudziestolecie międzywojenne i objęcie władzy przez rządy narodowe nie rozwiązało kwestii zwiększenia agrokultury, a tym samym podniesienia jakości bytu ludności rolniczej.

Na tle powyższych danych niezwykle wyraźnie można dostrzec różnicę pomiędzy Europą Środkowo-Wschodnią a Zachodnią oraz Stanami Zjednoczonymi, których zaplecze techniczne było już ówcześnie wysoko zautomatyzowane i dostosowane do masowego działania zmniejszającego zużycie siły roboczej, a tym samym zwiększającego wydajność pracy i dochodowośćc 2 .

Również w kontekście handlu zagranicznego jedynie Czechosłowacja i Austria zbliżały się do poziomu zachodnioeuropejskiego. W Polsce w okresie przedwojennym przeważał w eksporcie wywóz tanich surowców lub wyrobów mało przetworzonych. Przeciętna wartość 1 tony wywożonych do Europy wynosiła 75 zł, przywożonych - 281 zł, do Stanów Zjednoczonych odpowiednio: 316 zł i 620 zł. Było to pokłosiem jednego z najniższych wyników na Starym Kontynencie udziału w eksporcie wyrobów gotowych - 13\% wartości i najwyższego w przypadku surowców $-45 \%$.

Głównym źródłem zarobkowania ludności Międzymorza było rolnictwo, które charakteryzowało się znacznym nadmiarem żyjącej z roli ludności (zwłaszcza

${ }^{24}$ L.K., Zarys gospodarczy ziem Międzymorza Battycko-Śródziemnomorskiego i ich potencjat wojenny, „Bellona” [Londyn] 1946, z. 9-10, s. 46.

${ }^{25}$ Oceniało się, że w Europie Środkowo-Wschodniej około 100 mln osób związanych było z rolnictwem, w Polsce wg statystyki Ligi Narodów - ponad 70\%. H. Hessell Tiltman, Peasant Europe, London 1936, s. 16-17.

${ }^{26}$ Archiwum Biblioteki Jagiellońskiej, Przyb. 104/15, L. Barański, Memorandum on the Economic Integration of Western Europe, 1950, k. 14; L.K., Zarys gospodarczy ziem, s. 49-50.

${ }^{27}$ L.K., Zarys gospodarczy ziem, s. 51. 
w Polsce i krajach bałkańskich), niską wartością produkcji rolnej w porównaniu z krajami zachodniej Europy, poważną różnicą w wydajności pomiędzy nowoczesną gospodarką wielkorolną a bardzo małymi areałami, rażącą dysproporcją wyników produkcji zbożowej i hodowlanej, gdzie ta ostania pozostawała niezmodernizowana, a w efekcie jego niskim udziałem w dochodzie narodowym ${ }^{28}$. W kontekście, per capita, wahał się on $\mathrm{w}$ regionie w przeliczeniu na walutę brytyjską: od 12 - w Rumunii, 21.4 - w Polsce, do 34 funtów w Austrii i Czechosłowacji, gdy porównawczo w Niemczech i Francji wynosił 66 funtów, w Wielkiej Brytanii 120 funtów, natomiast w Stanach Zjednoczonych nawet 160 funtów ${ }^{29}$. Jeszcze gorzej przedstawiały się wskaźniki konsumpcji prywatnej, co łącznie z dochodem wskazywało na daleko odbiegający od Zachodu poziom społecznego ubóstwa i trudności z jego wyeliminowaniem. Można oceniać, że po zniszczeniach wojennych już tylko samodzielne wyrównanie do dochodu Czechosłowacji i Austrii wewnętrznych dysproporcji bez udziału zewnętrznego finansowania byłoby ważnym osiągnięciem całego regionu, chyba że zostałyby zastosowane drastyczne metody zwiększenia ogólnej dochodowości kosztem dalszego obniżenia się poziomu życia obywateli, jak w przypadku realizowanej polityki komunistycznej Rosji.

\section{POTENCJAŁ WOJSKOWO-GOSPODARCZY MIĘDZYMORZA}

Pragnąc określić potencjał militarny zintegrowanej Europy Środkowo-Wschodniej, należy określić determinujące go czynniki. Jednym z nich jest z pewnością wysoka kultura techniczna, wyrażająca się w możliwościach prowadzenia badań i poszukiwań, oparta na zarówno obfitych liczebnie i intelektualnie zasobach ludzkich, jak i ogromnych środkach finansowych. Istotne jest również odpowiednio duże uprzemysłowienie oraz zaplecze surowcowe pozwalające sprawnie wykorzystać rezultaty wyżej wymienionych działań pod kątem nowoczesnych środków walki, nieustannie udoskonalanych oraz uzupełnianych. Niezbędne jest także posiadanie przestrzeni operacyjnej, umożliwiającej realizację skutecznej strategii.

$\mathrm{Z}$ perspektywy prowadzenia wojny w warunkach pojawiających się na początku lat 50. XX wieku nowych narzędzi i technologii, głównymi elementami potencjału były:

a) stopień samowystarczalności surowcowej,

b) rozmiary uprzemysłowienia podmiotu,

c) poziom zamożności społeczeństwa.

\footnotetext{
28 Tamże.

${ }^{29}$ Tamże, s. 52.
} 
Posiłkując się wcześniej wskazanymi parametrami charakteryzującymi kraje Międzymorza, traktowanego jako całość polityczno-gospodarcza, określmy jego potencjał, konfrontując go następnie z możliwościami odbudowy silnej wielonarodowej i dobrze wyposażonej armii.

Analizując ten pierwszy z parametrów dostrzegamy, że składające się na niego zasoby oraz technologie wydobycia i obróbki jednoznacznie wskazują na nierealność osiągnięcia podobnego jak w krajach zachodnich oraz w Rosji stopnia samowystarczalności surowcowej. Olbrzymi rozwój ówczesnej techniki i związane z tym wymagania w zakresie dostarczenia odpowiednich komponentów, by wymienić tylko uran do broni atomowej, czy tez aluminium dla nowoczesnych samolotów, sprawiają, że lista importowa niezbędnych dla produkcji składników byłaby prawdopodobnie dłuższa, niż ta sporządzona dla produktów pochodzących z regionu. Przyglądając się trzydziestu najważniejszym ówcześnie surowcom przemysłowym, Międzymorze dysponowało jedenastoma z nich, gdy dla porównania: Zjednoczone Królestwo - 20, Rosja - 18. Jedynie Stany Zjednoczone dysponowały podobnym zasobem, ale o zdecydowanie lepszej strukturze. Wśród brakujących w regionie surowców znalazły się niezbędne do produkcji wojennej: cyna, wanad oraz kauczuk; względnie potrzebne z uwagi na własne niedobory, jak ropa naftowa, ruda żelaza i manganu, nikiel, bawełna ${ }^{30}$. Dodatkowo należałoby uwzględnić konieczność zabezpieczenia odpowiedniego poziomu ich zmagazynowania, co przy poważnych brakach finansowych oraz słabości nieskoordynowanej logistyki regionu byłoby praktycznie niemożliwym do zrealizowania wyzwaniem. Posiadanie złóż naturalnych, czy też nagromadzenie zasobów surowcowych, tylko w części rozwiązuje problem ukierunkowanej na wojnę produkcji. Ważniejsze, a jednocześnie uzupełniające jest posiadanie i właściwe wykorzystywanie infrastruktury produkcyjnej (odpowiednie uprzemysłowienie regionu), które pozwoliłoby szybko maksymalizować własną efektywność w jak najkrótszym czasie od zaistniałych potrzeb. Pod tym względem kraje Międzymorza, jak pokazały doświadczenia II wojny światowej, poza Czechosłowacją i Austrią, pozostawały w tyle za wielkimi mocarstwami, aczkolwiek już samo podniesienie przemysłu do tych dwóch wymienionych państw doprowadziłoby do względnej równowagi z potencjałem ludnościowym tej części Starego Kontynentu. Zatem jedynie podążanie ścieżką rozwinięcia pokojowej produkcji przemysłowej, następnie jej eksportu i zwiększenia wewnętrznej konsumpcji, dzięki bogaceniu się społeczeństwa, byłoby w stanie zabezpieczyć szybkie jej przestawienie na wojenne potrzeby do niezbędnych rozmiarów. Wymagałoby to nie tylko ogromnego i skoordynowanego wysiłku tworzących Międzymorze państw oraz pełnego czasowych wyrzeczeń wysiłku jego mieszkańców,

30 Tamże, s. 54. 
ale również wydatnego zewnętrznego wsparcia finansowego od niekonkurujących w stosunkach międzynarodowych podmiotów. Szczególnie jest to istotne, jeżeli zwrócimy uwagę na poziom zamożności społeczeństw w tej części Europy oraz koszty ewentualnej wojny. Warto w tym miejscu przybliżyć szacunki tej ostatniej w odniesieniu do zwycięskich Stanów Zjednoczonych, które wydało około $280 \mathrm{mld}$ dolarów, co per capita daje ponad 2 tys. dolarów w ciągu 4 lat, przy dochodzie narodowym w 1939 r. ponad 84 mld dolarów, czyli ponad 640 dolarów na głowę mieszkańca, bez uwzględniania zgromadzonych w amerykańskich oraz zagranicznych bankach dodatkowych ogromnych aktywów. W tym samym okresie - o czym wcześniej wspomniano - w państwach Europy Środkowo-Wschodniej dochód narodowy per capita wynosił 20 funtów, czyli około 80 dolarów $^{31}$. Nawet podwojenie tego wyniku w wyniku intensywnego rozwoju gospodarczo-społecznego wspartego zewnętrznymi kapitałami, co przewidywały niektóre projekty integracyjne, nie zbliżyłoby znacząco regionu do poziomu wiodącego mocarstwa, by myśleć o odgrywaniu w nowoczesnej wojnie istotnej roli. W opinii emigracyjnych ekspertów wysokość dochodu narodowego, przy ustabilizowaniu się sytuacji politycznej, mogłaby zostać dwukrotnie zwiększona w okresie 20 lat, co przy panującym pokoju pozwalałaby wydatkować, tak jak zakładano w Polsce, około 6\% budżetu państwa na potrzeby militarne. Posługując się wynikami 1938 r. można przyjąć, że przeznaczono by w okresie 15 lat sumarycznie około 19 mld ówczesnych złotych, mniej więcej po połowie, na sprzęt dla wszystkich rodzajów wojsk i wydatki wegetacyjne. Dla porównania: koszt wystawienia nowoczesnego korpusu pancerno-motorowego według etatów zbliżonych do brytyjskich (1 dywizja pancerna, 2 dywizje piechoty zmotoryzowanej plus 1 brygada o podobnych parametrach) wynosił z odpowiednią rezerwą sprzętu około 1.1 mld zł. Wielka Brytania w okresie najwyższego wysiłku wojennego wydawała $\mathrm{w}$ nieco ponad tydzień więcej, niż wynosił przedwojenny całoroczny budżet Polski ${ }^{32}$. Według analiz Antoniego Wasiutyńskiego, najpełniejszy nawet wzrost potencjału gospodarczego Polski nie rozwiązywałby zagadnienia obrony o własnych siłach. Proponowane przez elity rozwiązania federacyjne wzmacniałyby jej znaczenie w stosunkach międzynarodowych, ale jednocześnie zmuszały do koordynacji planów z kilkoma partnerskimi podmiotami ${ }^{33}$.

W podobny sposób można odnosić się do potencjalnej siły zbrojnej regionu, którą bazując na emigracyjnych kadrach, a następnie krajowych uzupełnieniach,

${ }^{31}$ A. WAsIUTYŃSKI, Znaczenie potencjału gospodarczego państwa w świetle doświadczeń II wojny światowej, „Bellona” [Londyn] 1946, z. 7, s. 54-56.

${ }^{32}$ L. K., Życie gospodarcze Polski w okresie między wojnami światowymi, „Bellona” [Londyn] 1947, z. 4, s.19.

33 A. WAsIUTYŃsKi, Znaczenie potencjału gospodarczego, s. 23. 
już po osiągnięciu alianckiego zwycięstwa można by było wykorzystać. Nie można było jednak zapomnieć, że Europa Środkowo-Wschodnia była na przełomie lat 40. i 50. XX wieku budującym potencjał gospodarczo-militarny zapleczem Rosji sowieckiej, z którego totalitarny system mógł, kosztem wymuszonych na jej społeczeństwach wyrzeczeniach, ,wycisnąć” więcej niż na Zachodzie materiału bojowego, szczególnie jeżeli przeanalizuje się produkcję sprzętu wojskowego na każdą tonę produkcji stali podczas II wojny światowej oraz kilka lat później34.

\section{BILANS ROZWAŻAŃ}

Podstawą emigracyjnego myślenia o bezpieczeństwie Europy Środkowo-Wschodniej była wola narodów do decydowania o własnej podmiotowości oraz brak ich akceptacji dla porozumienia opartego jedynie na przemocy, jeżeli nawet godzi się na takie rozwiązanie część świata politycznego, jak to miało miejsce w latach II wojny światowej, a które uważały za niemoralne i nierealne do utrzymania w dłuższej perspektywie. Wiązało się to z rosnącym przekonaniem o konieczności przyśpieszenia procesu integracji i zaproponowania nowych warunków współżycia sąsiadujących ze sobą narodów w ramach jednego podmiotu liczącego ponad 120 milionów osób, z blisko 10 wyznaniami religijnymi, kilkunastoma językami i tyluż odmiennymi kulturami. Towarzyszyć temu miało przekonanie związane z eliminacją lub ograniczeniem nawarstwionych od wieków sporów o władanie, granice, pierwotne interesy oraz hierarchie celów i wartości. Warunkiem przebudowy dotychczasowego układu politycznego Europy Środkowo-Wschodniej była zatem nie sama dobra wola elit i skuteczność dyplomatycznych zabiegów, ale możliwość dokonania głębokich przeobrażeń prawnych oraz poważne osiągnięcia w sferze międzynarodowego obyczaju. Całokształt tych koniecznych zmian można określić jako ideologiczne podłoże przyszłej konfederacji czy też związku państw. W największym stopniu powodzenie tegoż projektu zależałoby od nowego układu politycznego, w którym średnie i małe państwa musiałyby, o ile byłoby im to dane, znaleźć swoje akceptowalne przez wszystkie podmioty miejsce. Ich samodzielna mobilizacja nie byłaby możliwa przy zachowaniu dwublokowego rozwiązania w stosunkach międzynarodowych. Potencjał wojskowo-gospodarczy krajów Międzymorza traktowanych jako jedna całość gospodarczo-polityczna, byłby relatywnie słaby w porównaniu z potencjałem ludnościowym w warunkach ewentualnego światowego konfliktu, jeżeli Europa Środkowo-Wschodnia chciała-

${ }^{34}$ A. ZAUberman, Wkład satelitów do sowieckiego potencjalu wojenno-gospodarczego, „Bellona" [Londyn] 1951, z. 3, s. 38-41. 
by w nim uczestniczyć na tych samych zasadach i prawach, jak wielkie mocarstwa. Słuszna wydaje się konstatacja jednego z emigracyjnych analityków, że połączone w jakąś formę wspólnoty nie posiadałyby warunków, aby być samodzielnym agresorem, ale byłyby interesującym partnerem uzupełniającym część deficytowych zasobów $^{35}$. Z uwagi na związki cywilizacyjne z pewnością dotyczyłoby to zachodnich demokracji i ich projektów bezpieczeństwa z Paktem Północnoatlantyckim i Wspólnotami Europejskimi na czele. W zależności od tego, czy ówcześnie rozważana przyszłość zostałaby oparta w pewnym stopniu o sprawującą kontrolę nad światem globalną organizację, czy też ich związki polityczne i militarne z silnymi państwami, a być może utworzenie wspólnoty małych państw o potencjale pozwalającym na prowadzenie samodzielnej strategii międzynarodowej lub też w przypadku gwałtownych zmian, ogłoszenie narażonej na pogwałcenie neutralności, to w każdym z rozważanych rozwiązań narody regionu muszą ustalić indywidualne preferencje, by udało się stworzyć - względnie stabilną - podmiotowość wspólnoty. Przyjęte założenia muszą być funkcją wspólnych celów, a co za tym idzie - siły zbrojne muszą być wypadkową jednolitego planowania, realnych możliwości i interesów. Forsowane przez wychodźstwo rozwiązania wskazują na zakwalifikowanie do finalnych analiz trzecią z prezentowanych opcji. Jej przyjęcie, aczkolwiek nośne ideami, ale jakkolwiek ówcześnie trudne do zrealizowania w wypadku zwycięstwa koncepcji Zachodu, miało pewne szanse na realizację przy ich dobrej woli.

Odnosząc się do obrazu potencjału społeczno-gospodarczego Międzymorza, można wskazać na kilka kluczowych spraw rzutujących na ich potencjał, a w następstwie na samodzielną regionalną podmiotowość, a dalej - ich bezpieczeństwo. Trudno byłoby w krótkiej perspektywie czasowej zreformować nieefektywne rolnictwo, a w następstwie zwiększyć jego udział w dochodach narodowych. Niewykluczone, że udałoby się odpowiednio wykorzystywać posiadane zasoby surowcowe dla wzmocnienia potencjału regionu, ale po - przynajmniej częściowym - przetworzeniu i wyeksportowaniu powstałych na ich bazie produktów. Musiałby temu jednak towarzyszyć wspólnotowy plan industrializacji regionu i sprzyjające jego realizacji okoliczności, wzmocnione wolą współpracy ze strony konkurencyjnych podmiotów stosunków międzynarodowych. Należy również zauważyć, że tylko w następstwie powyższych zmian można byłoby mówić o początkach integracyjnego sukcesu w sferze militarnej, które byłyby obarczone kolejnymi, praktycznie nieosiągalnymi, rezultatami wynikającymi z sytuacji politycznej. Małe i średnie narody Europy Środkowo-Wschodniej nie miały jednak ówcześnie poważnych przesłanek do obrony swojej niezależności w oparciu o narodowe siły zbrojne, gdyż ich potencjał wojskowy nie pozwalał na wymaganą postępem technologicznym

\footnotetext{
${ }^{35}$ A. WasiUTYŃSKI, Znaczenie potencjału gospodarczego, s. 56.
} 
rozbudowę i utrzymywanie na nowoczesnym poziomie. Łatwo stąd o konstatację, że gwarancji własnego bezpieczeństwa musiałyby szukać w rozwiązaniach nie militarnych a politycznych. Te ostatnie powinny im zapewnić taką swobodę działania, aby ewentualne partnerstwo z silniejszym podmiotem (-ami) nie ograniczało nadmiernie ich suwerenności, w tym niezależnego politycznego zwierzchnictwa nad siłami zbrojnymi, by w przypadku złej woli z jego strony umożliwić sobie właściwe i skuteczne reagowanie. Nie sposób nie dostrzec w tym miejscu postępów nauki, która pozwoliła wytworzyć środki militarne, które osiągnęły już ówcześnie taką siłę niszczenia, że wojna przestała być narzędziem polityki, a obowiązujące jeszcze dekadę wcześniej koncepcje Clausewitza o wojnie absolutnej, stały się niemożliwe do zastosowania w dobie broni atomowych, co oznaczało przesunięcie się rywalizacji o prymat w świecie na inne, niedostępne Europie Środkowo-Wschodniej, płaszczyzny. Nie oznacza to jednak porzucenia obowiązku podążania za głównymi globalnymi graczami, w tym za ich nowoczesną myślą techniczną stanowiącą ówcześnie i dziś podstawę potencjału militarnego.

\section{BIBLIOGRAFIA}

Archiwum Biblioteki Jagiellońskiej, Przyb. 104/15, L. Barański, Memorandum on the Economic Integration of Western Europe, 1950.

Archiwum Instytutu i Muzeum gen. Sikorskiego w Londynie [AIPMS], sygn. A.XIX. Protokół konferencji przedstawicieli wojskowych 8 państw zza Żelaznej Kurtyny, odbytej w Paryżu w Bibliotece Polskiej w dniach od 12 do 15 marca 1952 r. 1/8, Plan tworzenie PSZ na Zachodzie ze stycznia $1953 \mathrm{r}$.

AIMPS, sygn. A.XIX. 1/49, Propozycje polskie na konferencję w dniach 26 i 30 lipca $1952 \mathrm{r}$.

AIMPS, sygn. A.XIX. 1/50, Memorandum to the Supreme Command of the Armed Forces of the Atlantic Pact in Europe, 1952.

AIMPS, sygn. A. XIX. 1/50, Joint Memorandum to the Supreme Command of the Armed Forces of the Atlantic Pact in Europe, 1952; Polish Affairs, 1952, nr 6.

Bartoszewicz H., Polityka Związku Sowieckiego wobec państw Europy Środkowo-Wschodniej w latach 1944-1948, Warszawa: Książka i Wiedza 1999.

B.M., Doktryny wojenne i struktury organizacyjne sił zbrojnych Zachodu i Wschodu, „Bellona" [Londyn] 1951, z. 3.

FrISZKE A., Życie polityczne emigracji, Warszawa: Biblioteka „Więzi” 1999.

GrYGaJtis K., Polskie idee federacyjne i ich realizacja w XIX i XX wieku, Częstochowa: WSP 2001.

Gross F., Federacje i konfederacje europejskie. Rodowód i wizje, Warszawa: Instytut Studiów Politycznych PAN 1994.

HABIELSKI R., Życie społeczne i kulturowe emigracji, Warszawa: Biblioteka Więzi 1999. 
Hessell Tiltman H., Peasant Europe, London 1936.

JeZERNíK V., Západoslovanská Federální Unie, London-Edinburgh 1942.

KisIELEWSKI T., Federacja środkowoeuropejska. Pertraktacje polsko-czechosłowackie 1939-1943, Warszawa: Ludowa Spółdzielnia Wydawnicza 1991.

Komarnicki T., Próba stworzenia związku polsko-czeskiego w okresie II wojny światowej, „Sprawy Międzynarodowe” 1(1947), nr 2-3.

KopaŃSKi S., Wspomnienia wojenne 1939-1946, Warszawa: Bellona 1990.

KuKIEl M., Książę Adam, Warszawa: PAVO 1993.

KsIąŻKIEwICZ M., Surowce mineralne Europy Środkowej, „Biuletyn Zachodnio-Słowiański” [Edinburgh] 1942, nr 6.

L.K., Zarys gospodarczy ziem Międzymorza Bałtycko-Śródziemnomorskiego i ich potencjał wojenny, „Bellona” [Londyn] 1946, z. 9-10.

LOCHER K., Konfederace nebo federální unie?, „Biuletyn Zachodnio-Słowiański” [Edinburgh] 1942, nr 1.

MALIK J., Economic aspects of post-war recontruction, „Biuletyn Zachodnio-Słowiański” [Edinburgh] 1942, nr 9.

Mania A., The National Security Council i amerykańska polityka wobec Europy Wschodniej w latach 1945-1960, „Zeszyty Naukowe Uniwersytetu Jagiellońskiego” 1994, t. 52.

MachCEWICZ P., Emigracja w polityce międzynarodowej, Warszawa: Biblioteka Więzi 1999.

MichaŁeK K., Mocarstwo, czyli historia Stanów Zjednoczonych Ameryki 1945-1992, Warszawa: Książka i Wiedza 1995.

Mochliński K., Polskie inicjatywy Federacji Europy, w: Akcja niepodległościowa na terenie międzynarodowym 1945-1990, red. T. Piesakowski, Londyn: Polskie Towarzystwo Naukowe na Obczyźnie 1999.

STACHOwski Z., The federation of Central European nations, „Biuletyn Zachodnio-Słowiański" [Edinburgh] 1942, nr 9.

Second Report of the Secretary of Defense and the annual reports of the Secretary of the Army, Secretary of the Navy, Secretary of the Air Force for the Fiscal Year 1949, United States Government Printing Office, Washington 1950.

Stern-Rubarth E., Exit Prussia: a plan for Europe, London: Duckworth 1940.

S. R., Kilka uwag o doktrynie wojennej Stanów Zjednoczonych i Rosji sowieckiej, „Bellona” [Londyn] 1948, z. 1.

TARKa K., Konfrontacja czy współpraca? Litwa w polityce Rządu Polskiego na uchodźstwie 1939-1945, Opole: Wydawnictwo Uniwersytetu Opolskiego 1998.

WAPIŃSKI R., Historia polskiej myśli politycznej XIX i XX wieku, Gdańsk: Arche 1997.

Warszawa nad Tamizą, Z dziejów polskiej emigracji politycznej po drugiej wojnie światowej, red. A. Friszke, Warszawa: Instytut Studiów Politycznych PAN 1994.

Wandycz P., Frendl L., Zjednoczona Europa. Teoria i praktyka, Londyn: Polonia Book Fund 1965.

WASIUTYŃSKI A., Znaczenie potencjału gospodarczego państwa w świetle doświadczeń II wojny światowej, „Bellona” [Londyn] 1946, z. 7. 
WoLAŃSkI S., Europa Środkowo-Wschodnia w myśli politycznej emigracji polskiej 19451975, Wrocław: Wydawnictwo Uniwersytetu Wrocławskiego 1996.

WoźNICZKa Z., Trzecia wojna światowa w oczekiwaniach emigracji i podziemia w kraju w latach 1944-1953, Katowice: Wydawnictwo Uniwersytetu Śląskiego 1999.

ZAĆMIŃSKI A., Emigracja polska w Wielkiej Brytanii wobec możliwości wybuchu III wojny światowej 1945-1954, Bydgoszcz: Wydawnictwo Akademii Bydgoskiej im. Kazimierza Wielkiego 2003.

ZAPART R., Projekt Konstytucji Federacji Środkowo-Europejskiej jako wyraz integracyjnego idealizmu w budowie systemu regionalnego bezpieczeństwa w myśli politycznej polskiego wychodźstwa w XX wieku, „Studia Polonijne” 39(2018).

ZAPART R., Polityczno-militarne znaczenie oddziałowych kół wojskowych z perspektywy potencjalnego światowego konfliktu w latach 50. XX wieku, w: Bezpieczeństwo Europy, bezpieczeństwo Polski, t. V: Metamorfozy bezpieczeństwa, teraźniejszość i przyszłość, red. E. Maj, W. Sokół, A. Szwed-Walczak, Ł. Jędrzejewski, Lublin: UMCS 2017.

ZAUBERMAN A., Wkład satelitów do sowieckiego potencjału wojenno-gospodarczego, „Bellona" [Londyn] 1951.

ZDZIECHOWSKI J., Polish Affairs, 1952, nr 6.

Zlatoper G., Federation in the common interest, „Biuletyn Zachodnio-Słowiański” [Edinburgh] 1942, nr 9.

ZnamierowsKa-RakK E., Federacja Słowian Południowych w polityce Bułgarii po II wojnie światowej. Korzenie, próby realizacji, upadek, Warszawa 2005.

Z.S., Związek polityczny narodów Europy Środkowej, „Biuletyn Zachodnio-Słowiański” [Edinburgh] 1941, nr 3.

Z.S., Federacja Zachodnio-Słowiańska, „Biuletyn Zachodnio-Słowiański” [Edinburgh] 1940, nr 2.

Z.S., Federacja Zachodnio-Słowiańska, „Biuletyn Zachodnio-Słowiański” [Edinburgh] 1940, nr 1.

\section{ZNACZENIE EUROPY ŚRODKOWO-WSCHODNIEJ W ZIMNOWOJENNYCH KONCEPCJACH POLSKIEGO WYCHODŹSTWA NA TLE POTENCJAŁU WIELKICH MOCARSTW}

\section{Streszczenie}

Kluczowe dla podjętych rozważań naukowych pozostawało pytanie o niezależność Europy Środkowo-Wschodniej z perspektywy posiadanego przez nią potencjału gospodarczo-militarnego w kontekście oczekiwań środowisk emigracyjnych związanych ze zmianami politycznymi w regionie w następstwie ewentualnego wybuchu III wojny światowej w połowie XX wieku. W świetle przywołanych przez autorów artykułu danych z różnych obszarów badawczych, małe i średnie narody tej części Starego Kontynentu nie miały ówcześnie poważnych przesłanek do 
obrony swojej niezależności na podstawie narodowych sił zbrojnych, gdyż ich potencjał wojenny nie pozwalał na wymaganą postępem technologicznym (broń nuklearna) ich rozbudowę i utrzymywanie na nowoczesnym poziomie, w odróżnieniu od dwóch wielkich mocarstw, Stanów Zjednoczonych i Związku Radzieckiego i związanych z nimi państw. Gwarancji podmiotowości musiałyby zatem poszukiwać w przyszłości w rozwiązaniach politycznych, w tym przede wszystkim partnerstwie z silniejszym podmiotem podzielającym ich wizję wolności, integracji oraz systemu zbiorowego bezpieczeństwa.

Słowa kluczowe: Europa Środkowo-Wschodnia; środowiska emigracyjne; potencjał gospodarczo-militarny Europy

\section{THE IMPORTANCE OF CENTRAL AND EASTERN EUROPE IN THE COLD WAR CONCEPTS OF POLISH EXILE AGAINST THE BACKGROUND OF THE POTENTIAL OF THE GREAT POWERS}

The article discusses the question of Central and Eastern Europe's independence from the perspective of its economic and military potential, in the context of the expectations of the émigré communities with regard to political changes in the region following the possible outbreak of World War III in the mid-20th century. In the light of the data from various areas of research cited by the authors of the article, the small and medium-sized nations of this part of the Old Continent did not have at that time any serious reason to defend their independence on the basis of their national armed forces, because their military potential did not allow them to develop and maintain them at a modern level, as required by technological progress (nuclear weapons), unlike the two great powers at that time - the United States and the Soviet Union, as well as the countries associated with them. Thus the Central and Eastern European countries would have to seek the future guarantees of their independence in political solutions, including, above all, partnership with a stronger entity that shared their vision of freedom, integration and collective security.

Keywords: Central and Eastern Europe; émigré communities; Europe's economic and military potential 